\title{
Effect of Storage Temperature on the Quality of Kepok Banana (Musa paradisiaca formatypica)
}

\author{
Andi Nur Faidah Rahman*, Victor Crystaline Muhammad and Februadi Bastian \\ Department of Agriculture Technology, Faculty of Agriculture, Hasanuddin University, Makassar, \\ Indonesia
}

\begin{abstract}
Kepok bananas are often be processed into several products, while they also have an ABB genotype. The letter B indicates the possession of stronger resistance to disease and chilling injury in cold temperatures storage that extends bananas' shelf life by decelerating its respiration and enzymatic activity. Therefore, this study aims to observe storage temperatures' effect on kepok banana's quality and shelf life and to determine the optimum storage temperature. The method used was storage at room temperature, $15^{\circ} \mathrm{C}$, and $10^{\circ} \mathrm{C}$ until the banana became damaged. The parameters observed were respiration patterns, weight loss, hardness, fruit skin color, total acid, vitamin C, $\mathrm{pH}$, and total soluble solids. The results showed bananas stored at cold temperatures $\left(10^{\circ} \mathrm{C}\right.$ and $\left.15^{\circ} \mathrm{C}\right)$ lasted up to 20 days while those at room temperature only lasted for 10 days. Also, the ones stored at $10^{\circ} \mathrm{C}$ displayed no symptoms of chilling injury.
\end{abstract}

Article History

Received July 30, 2020

Accepted June 21, 2021

Keyword

Kepok banana (Musa paradisiaca

formatypica), Cold

temperature $\left(10^{\circ} \mathrm{C}-\right.$

$\left.15^{\circ} \mathrm{C}\right)$, and Storage.

\section{Introduction}

Indonesia is one of the countries with the largest amount of banana production globally, where the production in 2018 reached 7.26 million tons (1). Many types of bananas grow in South Sulawesi, based on fruit flesh color, kepok banana has 2 types, namely white and yellow, besides it is a climacteric fruit that has a short shelf life after being harvested because the respiration rate increases. In appropriate treatment of the harvested fruit causes quicker damage, due to continuous microbial and enzymatic activity (2).

Bananas are made of diploid, triploid, and tetraploid genomes consisting of letters $A$ and B. Kepok bananas have ABB genotype, where the letter $B$ indicates that this type has stronger resistance to disease (3) and does not experience browning easily (4).

Generally, fruits and vegetables have a short life because of their high water content (80\%-90\%). Therefore to extend the shelf life, they need to be stored at low temperatures to decelerate the respiration, enzymatic and microbial activity (2). Bananas are often stored at $10-15^{\circ} \mathrm{C}$, but kepok banana's optimum storage temperature to produce good quality, promote long shelf life, and avoid chilling injury effects is not yet known. 


\section{Materials and Methods}

The tools used included aquarium pumps, large jars, knives, thermometer, refrigerator, camera, chromameter, biuret, digital scale, penetrometer, $\mathrm{pH}$ meter, and refractometer.

Also, the materials used were Kepok banana with a maturity index of 4 (more dominant yellow skin color than the green) obtained from the traditional market of Makassar in South Sulawesi, distilled water, phenolphthalein, $\mathrm{NaOH}$, iodine solution, $\mathrm{HCl}$, buffer with $\mathrm{pH} 7$, and $\mathrm{Ca}(\mathrm{OH})_{2}$.

\subsection{Research Procedure}

The procedure used was carried out in 3 stages, namely fruit sorting, storage by temperature treatment, and observation.

\subsubsection{Fruit Sorting}

To obtain the kepok bananas with uniform conditions, the mature ones were sorted first. The indicator used in sorting is based on the fruit skin color, where yellow was more dominant than green (Color Index 4). Banana fruits that have been sorted and were then cleaned by wiping using a cloth to remove all dirt stains.

\subsubsection{Storage with Temperature Treatment}

Subsequent to sorting, the bananas were given storage treatment with 3 different temperatures, namely room temperature $\left(28^{\circ} \mathrm{C}-31^{\circ} \mathrm{C}\right)$ with $70 \% \mathrm{RH}$, and cold temperatures of $15^{\circ} \mathrm{C}$ and $10^{\circ} \mathrm{C}$ with $85 \% \mathrm{RH}$.

\subsubsection{Observations}

Observations were carried out until the $20^{\text {th }}$ days, with an observation span of 2 days. The indicators used as parameters were respiration rate, weight loss, fruit skin color, hardness, $\mathrm{pH}$, total acid, vitamin $\mathrm{C}$, and total soluble solids. All parameters observed were repeated thrice except respiration rate that was only once.

\subsubsection{Respiration Rate}

The principle of respiration rate measurement was utilizing $\mathrm{NaOH}$ solution to bind the $\mathrm{CO}_{2}$ gas produced by bananas. Then, the amount of $\mathrm{CO}_{2}$ bound to the $\mathrm{NaOH}$ solution was titrated with $\mathrm{HCl}$ solution. The respiration rate was calculated using the following formula (5):

$$
\begin{gathered}
\text { Respiration Rate }=\frac{(m L \text { Blanco }-m L \text { Sample }) \times N \text { HCl } x \text { BM CO2 }}{2} \\
\mathrm{~N} \mathrm{HCl}=0.5 \mathrm{~N} \quad \mathrm{BM} \mathrm{CO}_{2}=40
\end{gathered}
$$




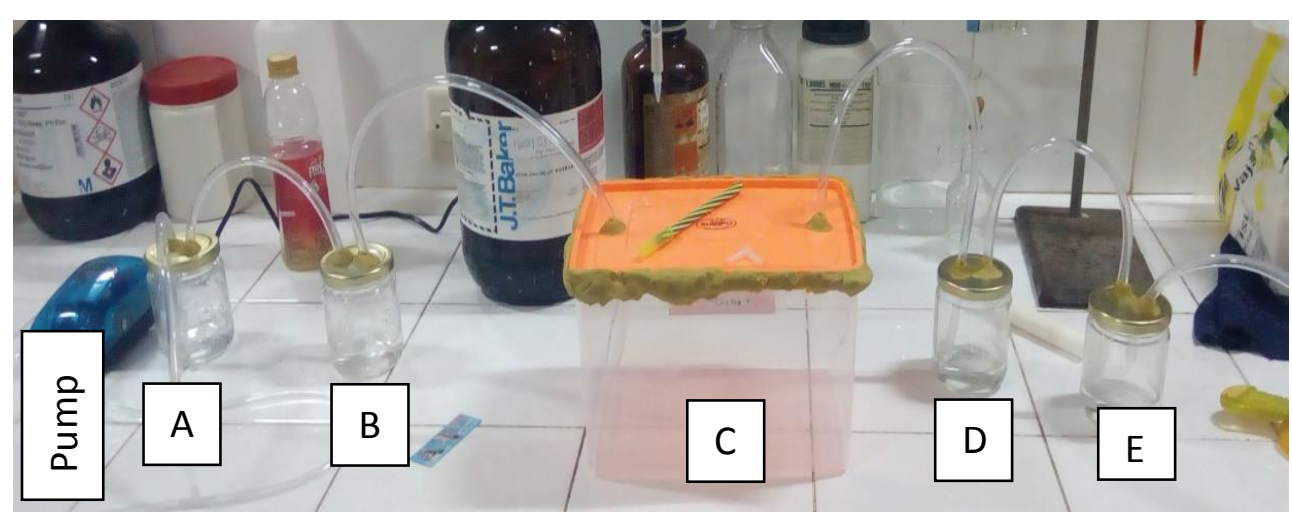

Figure 1. Measuring Respiration Rate

$$
\begin{array}{ll}
A=50 \mathrm{~mL} \mathrm{Ca}(\mathrm{OH})_{2} & D=50 \mathrm{~mL} \text { of } 0.5 \mathrm{~N} \mathrm{NaOH} \\
B=50 \mathrm{~mL} \text { of } 0.1 \mathrm{~N} \mathrm{NaOH} \quad \mathrm{E}=50 \mathrm{~mL} \text { of } 0.5 \mathrm{~N} \mathrm{NaOH} \\
C=\text { Sample }
\end{array}
$$

The air was passed to container $A$ first to bind $\mathrm{CO}_{2}$, then air released was flown again into container $\mathrm{B}$. The air that came out was considered to be free of $\mathrm{CO}_{2}$ and was then passed to container $C$ which contained $1 \mathrm{~kg}$ of bananas. Furthermore, the air released was passed to container $\mathrm{D}$ to bind the $\mathrm{CO}_{2}$ gas produced by the bananas during respiration. To bind the remaining $\mathrm{CO}_{2}$, the last released air was then passed to container $\mathrm{E}$.

\subsubsection{Weight Loss}

The weight loss was determined by weighing the sample before and after storage, hence calculated using the following formula (6):

$$
\begin{aligned}
& \text { Weight Loss }=\frac{A-B}{A} \times 100 \% \\
& A=\text { Before Storage } \quad B=\text { After Storage }
\end{aligned}
$$

\subsubsection{Fruit Skin Color Measurement using Colorimeter Method}

The sample color was measured at one point, while a button was pressed to commence the process. The color standard used was based on the Hunter $L$ scale, $a$, and $b$, where $L$ represents the color brightness (range $=0-100$; number increases $=$ brighter). Letter a represents red/green [range $=(-128)-127 ;(+)$ the color is red; $(-)$ the color is green], and the letter $b$ represents the yellow/blue [range $=(-128)-127 ;(+)$ the color is yellow; $(-)$ the color is blue] (7). 


\subsubsection{Fruit Hardness Determination using Penetrometer Method}

The material's hardness was obtained by pressing the sample on the penetrometer using standard presses such as cones (cone-shaped needles), needles, or rods that are submerged in the sample. The sample pressures' measurement results showed a material's level of hardness or softness depends on the sample's conditions such as size, press weight, geometry, and time. The softer the sample, the deeper the penetrometer suppressor sinks and shows a greater number (8).

\subsubsection{Determination of $\mathrm{pH}$}

$\mathrm{pH}$ level was measured by $\mathrm{pH}$ meter, where $5 \mathrm{~g}$ banana flesh was collected, then mashed and homogenized with $5 \mathrm{~mL}$ of distilled water. Next, the solution was dropped into a $\mathrm{pH}$ sensor on the $\mathrm{pH}$ meter which automatically displayed the $\mathrm{pH}$ value. Before use, the $\mathrm{pH}$ meter was calibrated first with a $\mathrm{pH}$ buffer of 7 , and after it was cleaned with distilled water (9).

\subsubsection{Determination of Vitamin C using lodine Method}

The vitamin C content was determined by using the iodine method, where $10 \mathrm{~g}$ of crushed banana material was collected. This was then put into a measuring flask containing distilled water up to $100 \mathrm{~mL}$ and diluted. Afterwards, $25 \mathrm{~mL}$ of the solution was put into the erlenmeyer flask. Then, 3 drops of starch indicator were added with $0.1 \mathrm{~N}$ iodine solution until it appeared blue. The vitamin $\mathrm{C}$ levels were calculated by using the formula below (10):

$$
\text { Vitamin } C=\frac{m L \text { iod } \times 0.88 \times F P}{\text { Sample Weight } \times 1000} \times 100 \%
$$

$$
\mathrm{FP}=4
$$

\subsubsection{Acidity Testing}

Acidity testing stages were carried out using the titration method to determine the level of lactic acid that was formed. Furthermore, $20 \mathrm{~mL}$ of the samples were obtained and 3 drops of the indicator $1 \%$ phenolphtalein (PP) were added. These were titrated with $0.1 \mathrm{~N}$ $\mathrm{NaOH}$ until the color changes to a constant pink, then the acidity was calculated using the formula below (11):

$$
\text { Acidity }=\frac{V 1 \times N \times B}{V 2 \times 1000} \times 100 \%
$$

V1: Volume of $\mathrm{NaOH}(\mathrm{mL})$

V2: Volume of the sample $(\mathrm{mL})$

$\mathrm{N}$ : Normality of $\mathrm{NaOH}(0.1 \mathrm{~N})$ 


\subsubsection{Testing of Total Soluble Solids}

Total soluble solids were analyzed by using a refractometer. Five gram of banana flesh was collected, then mashed and homogenized with $5 \mathrm{~mL}$ of distilled water. The solution was placed on the Refractometer lens to read the results. Before and after the reading, the refractometer prism was cleaned with aquadest. The number on the refractometer was the total soluble solid ( ${ }^{\circ}$ Brix) level (2).

\subsection{Research Methods}

The method used was a completely randomized design (CRD) consisting of one factor, namely the temperature treatment including room Temperature $15^{\circ} \mathrm{C}$ and $10^{\circ} \mathrm{C}$.

\subsection{Data Analysis}

Data from all parameters were analyzed and then processed through analysis of variance (ANOVA) with three replications. The differences between treatments were further assessed by the Duncan test. The software used was Microsoft Excel 2010 and SPSS version 23 with a confidence level of 0.05 .

\section{Results and Discussion}

Figure 2 shows kepok bananas stored at room temperature only lasted until the 10th day, while storage at cold temperatures $\left(10^{\circ} \mathrm{C}\right.$ and $\left.15^{\circ} \mathrm{C}\right)$ lasted until the $20^{\text {th }}$ days. Therefore, testing for all parameters was carried out until the 10th day for room temperature storage and until the $20^{\text {th }}$ day for storage at $10^{\circ} \mathrm{C}$ and $15^{\circ} \mathrm{C}$ storage.

\subsection{Respiration rate}

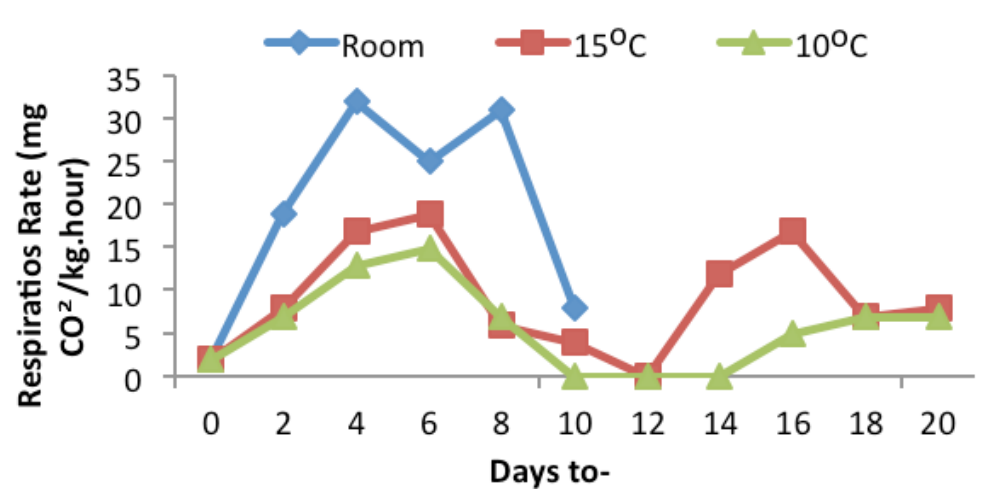

Figure 2. Relationship between storage time and kepok bananas' respiration rate at room temperature, $15^{\circ} \mathrm{C}$, and $10^{\circ} \mathrm{C}$.

The respiration rate measurement results showed all treatments had climacteric respiration patterns. Climacteric fruit has a pattern of respiration rate that increases during the ripening phase and decreases in the senescence phase (12). During the ripening process, $\mathrm{CO}_{2}$ gas production tends to increase and reach a certain peak point, then decrease after 
the maturation is completed. Hence, the bananas stored at room temperature reached the respiration peak on day $4^{\text {th }}$, while those at $10^{\circ} \mathrm{C}$ and $15^{\circ} \mathrm{C}$ reached the respiration peak on day $6^{\text {th }}$.

ANOVA test results showed room temperature storage was significantly different when compared to cold temperatures $\left(15^{\circ} \mathrm{C}\right.$ and $\left.10^{\circ} \mathrm{C}\right)$, because at room temperature the respiration, enzymatic and microbial activity was faster than at cold temperature. This process is marked by a drastic change in the banana peel color from green to yellow. The respiration rate of bananas stored at cold temperatures is relatively stable compared to those at room temperature. This happens because low temperatures decelerate respiration, microbial and enzymatic activity (13).

\subsection{Weight Loss}

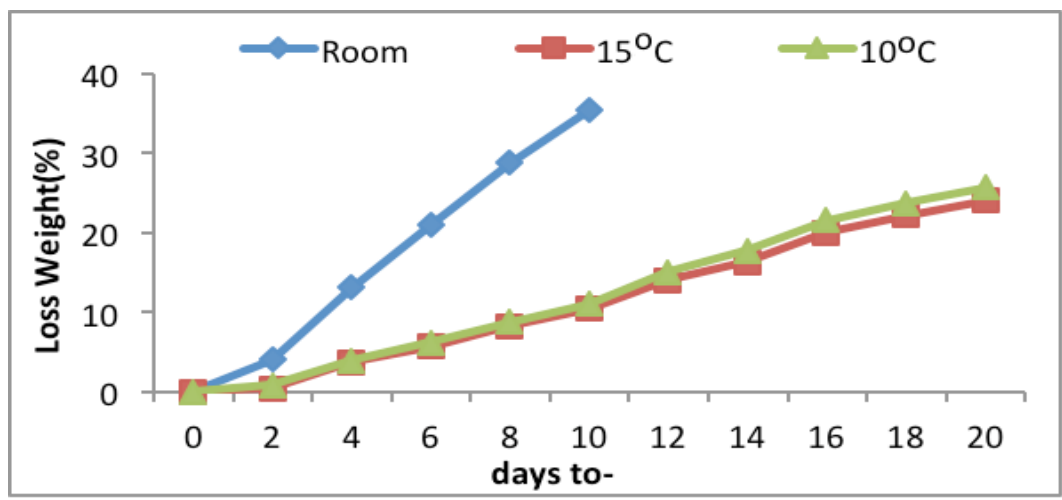

Figure 3. Relationship between storage time and weight loss of kepok banana at room temperature, $15^{\circ} \mathrm{C}$, and $10^{\circ} \mathrm{C}$.

Figure 3 shows the bananas stored at room temperature had a higher increase in weight loss compared to those at $15^{\circ} \mathrm{C}$ and $10^{\circ} \mathrm{C}$. ANOVA test results also showed that room temperature storage was significantly different when compared to cold temperatures $\left(15^{\circ} \mathrm{C}\right.$ and $10^{\circ} \mathrm{C}$ ). Decrease in weight loss occurs because, during bananas storage and ripening, starch is hydrolyzed to simple sugar. The more starch is converted to sugar, the higher the weight loss (14).

High temperatures cause a faster transpiration process that subsequently reduces fruit water content to ensure greater weight loss compared to low temperatures. In addition, high temperatures cause increased respiration. Water loss in large quantities cause a decrease in fruit's freshness, hence the greater the water loss the more fruit skin becomes dry and wrinkled (15). Storage at low temperatures and high humidity reduces the loss of fruit moisture (16). When water vapor loss is suppressed, it is hoped to reduce weight loss and the level of fruit hardness or skin resistance. 


\subsection{Skin Color}

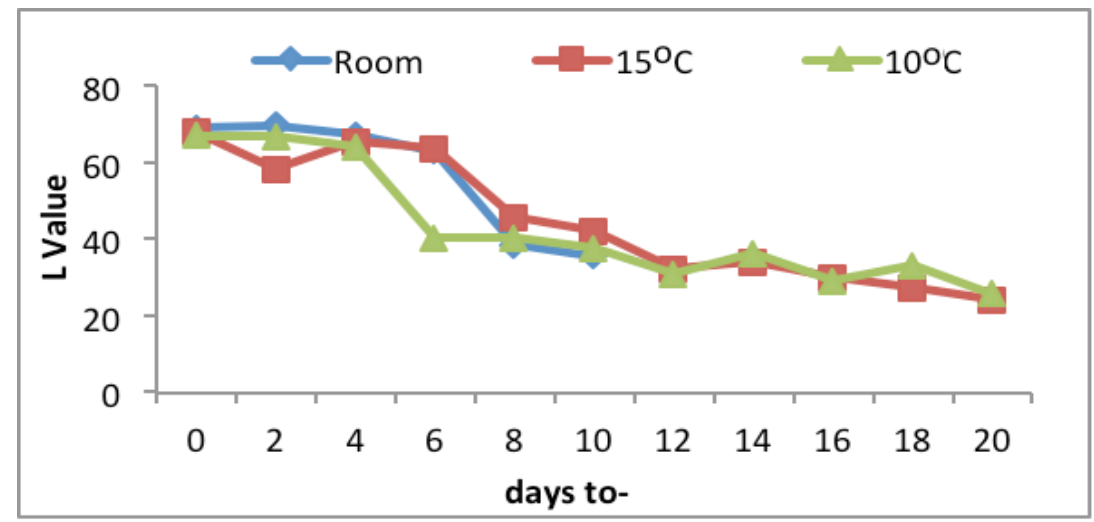

Figure 4. Relationship of storage time with kepok banana $L$ value at room temperature, $15^{\circ} \mathrm{C}$, and $10^{\circ} \mathrm{C}$.

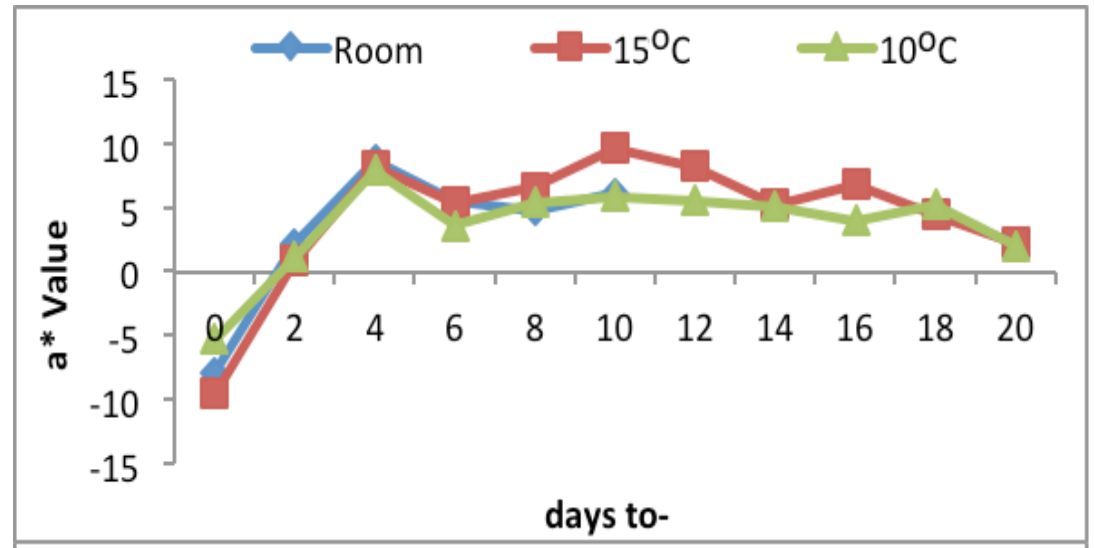

Figure 5. Relationship of storage time with a * kepok banana value at room temperature, $15^{\circ} \mathrm{C}$, and $10^{\circ} \mathrm{C}$.

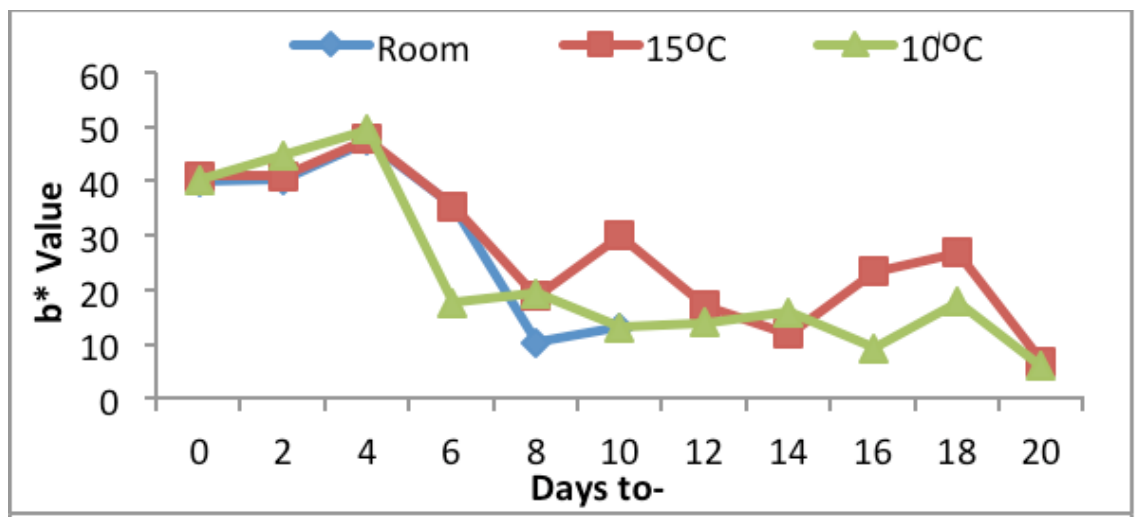

Figure 6. Relationship of storage time with $b *$ value of kepok banana at room temperature, $15^{\circ} \mathrm{C}$, and $10^{\circ} \mathrm{C}$.

During the ripening process, the value of a* increased, while the values of brightness and b* began to decrease, because, at this period, chlorophyll degradation occurred followed by 
pure carotenoids formation (17). Chlorophyll reshuffling occurred immediately after the climacteric peak was reached (4). Chlorophyll degradation is influenced by ethylene and temperature increases. At $22^{\circ} \mathrm{C}$, chlorophyll degradation (60\% per day) is maximal, while at temperatures below $15^{\circ} \mathrm{C}$ and above $40^{\circ} \mathrm{C}$ it is very small (18). ANOVA test results showed room temperature storage was not significantly different when compared to cold temperatures $\left(15^{\circ} \mathrm{C}\right.$ and $\left.10^{\circ} \mathrm{C}\right)$ at the confidence level of $0.05(p<0.05)$.

\subsection{Hardness}

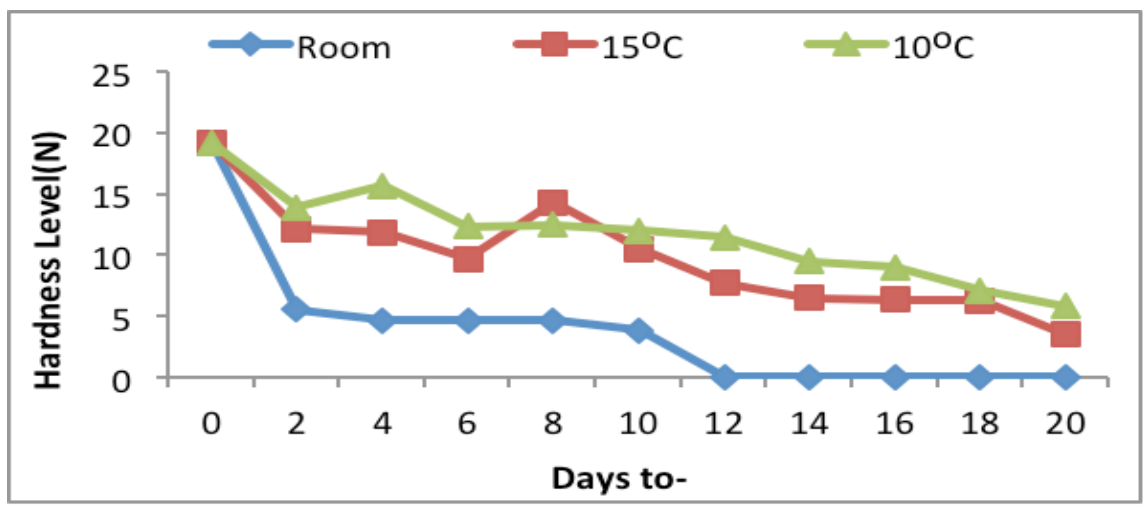

Figure 7. Relationship of storage time with kepok bananas' hardness level at room temperature, $15^{\circ} \mathrm{C}$ and $10^{\circ} \mathrm{C}$.

According to Figure 7, the samples' hardness level at room temperature storage decreased rapidly. ANOVA test results showed that room temperature storage was significantly different compared to cold temperatures $\left(15^{\circ} \mathrm{C}\right.$ and $\left.10^{\circ} \mathrm{C}\right)$. Bananas' hardness occurs due to the presence of pectin contained in the peels. Meanwhile, fruit flesh softening occurs due to water loss and starch conversion into sugar, and this is quicker at room temperature than at cold temperatures. Banana flesh softening occurs in three processes, including starch conversion into sugar, pectin components' breakdown, and water transfer from the fruit skin to the flesh during the ripening process (19).

\section{$3.5 \mathrm{pH}$}

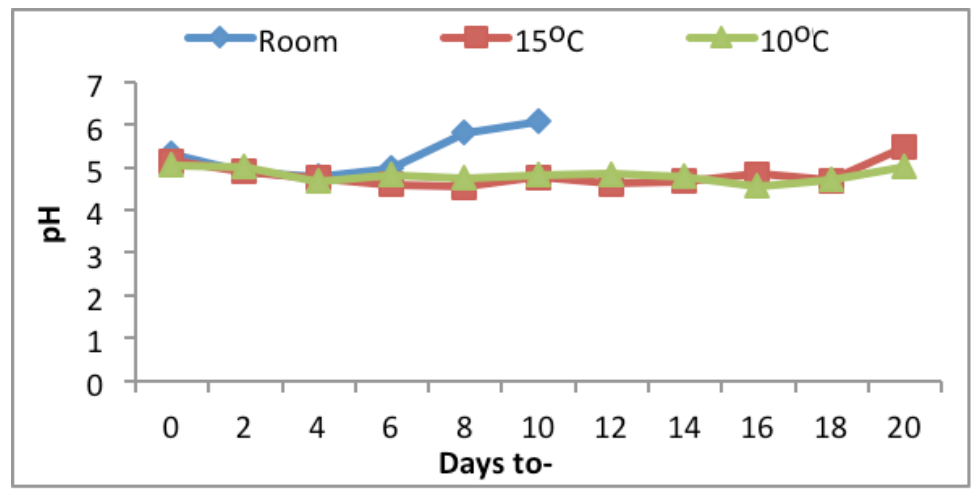

Figure 8. Relationship of storage time with kepok bananas' pH value at room temperature, $15^{\circ} \mathrm{C}$, and $10^{\circ} \mathrm{C}$. 
Based on the graph, the $\mathrm{pH}$ value decreased until the fourth day and then it increased. This was due to acid compounds' breakdown, thereby reducing the $\mathrm{pH}$ value. During the ripening process, a fruit's total acid increases, leading to a $\mathrm{pH}$ decrease. This continues until the maximum point and then decreases slightly in line with the ripe fruit (20).

ANOVA test results showed room temperature storage was significantly different when compared to cold temperatures $\left(15^{\circ} \mathrm{C}\right.$ and $\left.10^{\circ} \mathrm{C}\right)$. This occurred because the decrease in $\mathrm{pH}$ of bananas stored at cold temperatures was slower than at room temperature. Fruits containing a low $\mathrm{pH}$ level have longer durability than those containing a higher $\mathrm{pH}$, and it is influenced by changes in the total amount of acid content (21).

\subsection{Vitamin C}

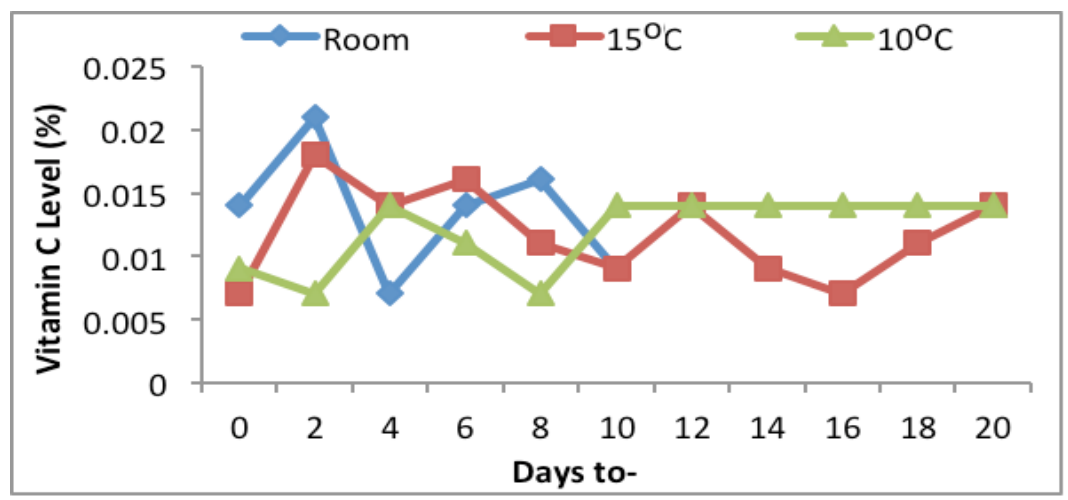

Figure 9. Relationship of storage time with vitamin C levels in kepok bananas at room temperature, $15^{\circ} \mathrm{C}$, and $10^{\circ} \mathrm{C}$.

Figure 9 shows the vitamin $C$ in kepok bananas during storage at room and cold temperatures. The bananas stored at room temperature had a faster increase in vitamin $\mathrm{C}$, then sequentially followed by those stored at 15 and $10^{\circ} \mathrm{C}$. Bananas' vitamin $\mathrm{C}$ levels increase due to the glucose content's biosynthesis, where sugar levels' increase is also followed by an increase in the fruit respiration rate (22). Refined sugar from the starch content is synthesized into vitamin $C$ to ensure the levels increase continuously during the maturation process (23). Therefore, bananas' maturity and vitamin C levels increase correspondingly.

ANOVA test results showed the room temperature storage was not significant when compared to cold temperatures $\left(15^{\circ} \mathrm{C}\right.$ and $\left.10^{\circ} \mathrm{C}\right)$. However, vitamin $\mathrm{C}$ levels' decrease at the room temperature was faster than at the cold temperatures, because higher temperatures increase the respiration process and cause a decrease in vitamin $\mathrm{C}$ levels more quickly. 


\subsection{Total Acid}

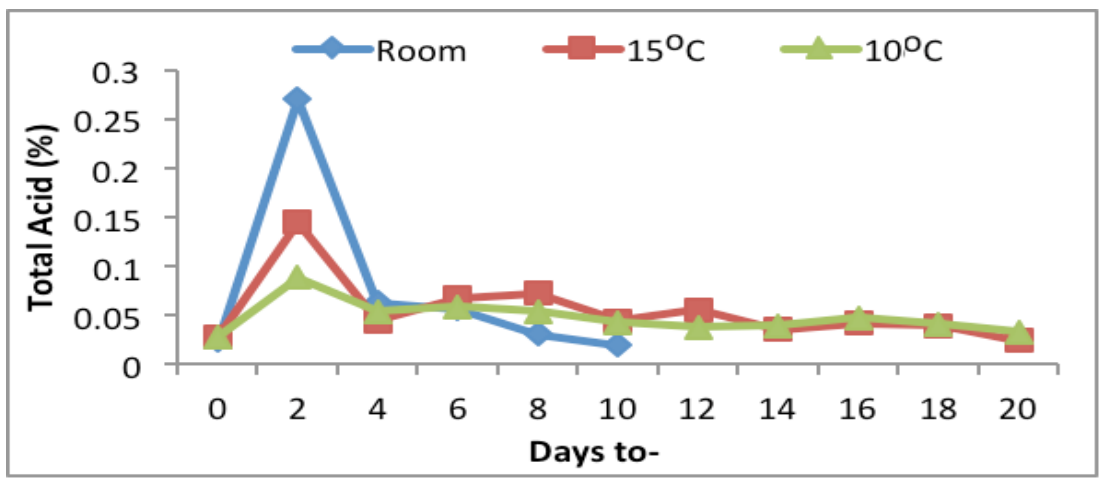

Figure 10. Relationship of storage time with kepok bananas' total acid at room temperature, $15^{\circ} \mathrm{C}$, and $10^{\circ} \mathrm{C}$.

Figure 10 shows storage time's relationship with total acid of kepok banana at room temperature $15^{\circ} \mathrm{C}$ and $10^{\circ} \mathrm{C}$. Total acid levels increased on the second day of storage and decreased dramatically on the $4^{\text {th }}$ day until the last day. The highest total acid value occurred only at the beginning of storage because the fresh fruit tissue produced organic acids in high amounts. The high total acid value at the beginning of storage occurred because the fruit network was still fresh, hence organic acids were produced in the Kreb cycle. The total acid value at cold storage was lower than at the room temperature, this proves that the temperature decelerated enzymes' work in the fruit to lower its metabolic activity. The fruit's organic acid content initially increased and reached the maximum level and then decreased slowly at maturation (24). ANOVA test results showed room temperature storage was not significantly different when compared to cold temperatures $\left(15^{\circ} \mathrm{C}\right.$ and $\left.10^{\circ} \mathrm{C}\right)$. Also, the increase in total acid at room temperature was higher than at cold temperatures.

\subsection{Total Soluble Solid (TSS)}

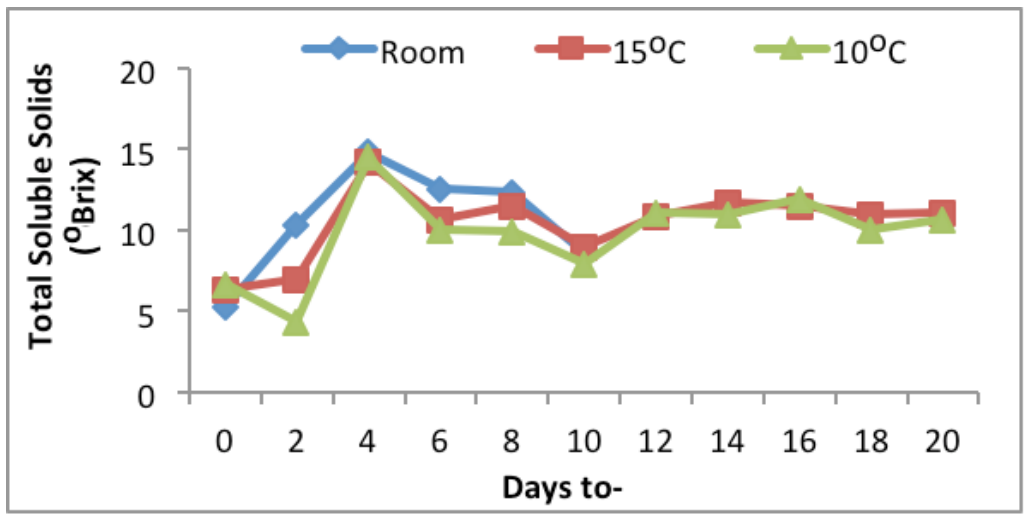

Figure 11. Relationship of storage time with kepok bananas' total soluble solid at room temperature, $15^{\circ} \mathrm{C}$, and $10^{\circ} \mathrm{C}$. 
Figure 11 shows an increased total soluble solids (TSS) in the kepok bananas stored at room temperature, $15^{\circ} \mathrm{C}$, and $10^{\circ} \mathrm{C}$, because, during the ripening process, starch content was converted into a water-soluble simpler sugar compound. Because of continuous respiration, starch utilization was replaced by sugar to produce energy. During storage, total soluble solid increases due to insoluble starch hydrolysis into a water-soluble sugar, while TSS levels decrease because the sugar is oxidized to conduct respiration (17). ANOVA test results showed room temperature storage was not significantly different when compared to cold temperatures $\left(15^{\circ} \mathrm{C}\right.$ and $\left.10^{\circ} \mathrm{C}\right)$.

\section{Conclusions}

The conclusions drawn from this study are as follow:

1. Storage temperature significantly influences Kepok bananas' quality in the parameters of respiration rate, weight loss, hardness level, and $\mathrm{pH}$ value. Meanwhile, the vitamin $\mathrm{C}$ levels, total acid, color, and total soluble solids (TSS) are not significantly affected.

2. Kepok bananas' optimum storage temperature is $15^{\circ} \mathrm{C}$, and no chilling injury was shown at $10^{\circ} \mathrm{C}$.

3. The maximum storage time of Kepok bananas at room temperature is 10 days, while at cold temperatures $\left(15^{\circ} \mathrm{C}\right.$ and $\left.10^{\circ} \mathrm{C}\right)$, it is 20 days.

\section{References}

1. Indonesia KPR. Produksi Pisang Menurut Provinsi. Kementerian Pertanian Republik; 2019.

2. Sri Rejeki Saragih C. Penerapan Penyimpanan Dingin untuk Pisang Raja Sere (Musa acuminata colla). Bogor: Sekolah Pascasarjana IPB; 2018.

3. Borges C V, Maraschin M, Coelho DS, Leonel M, Gomez HAG, Belin MAF, et al. Nutritional value and antioxidant compounds during the ripening and after domestic cooking of bananas and plantains. Food Res Int. 2020;132:109061.

4. Yang X, Zhang Z, Joyce D, Huang X, Xu L, Pang X. Characterization of chlorophyll degradation in banana and plantain during ripening at high temperature. Food Chem. 2009;114(2):383-90.

5. Sun F, Zhang P, Guo M, Yu W, Chen K. Burdock fructooligosaccharide induces fungal resistance in postharvest Kyoho grapes by activating the salicylic acid-dependent pathway and inhibiting browning. Food Chem. 2013;138(1):539-46.

6. Hailu M, Workneh TS, Belew D. Effect of packaging materials on shelf life and quality of banana cultivars (Musa spp.). J Food Sci Technol. 2014;51(11):2947-63.

7. Arda G, Utama IMS, Yulianti NL, Aviantara IGNA. Aplikasi Pelapisan dengan Beberapa Jenis Minyak Nabati dan Antimikroba untuk Meningkat Daya Simpan Buah Tomat (Lycopersicon esculentum Mill.) dalam Suhu Ruang. Universitas Udayana; 2013.

8. Suwanto PE, Yanuarita DH. Studi dan Perancangan Penetrometer Digital sebagai Alat Uji Konsistensi Bahan Berbasis Mikrokontroler. Inst Teknol Sepuluh Novemb. 2012;

9. Rodrigues AS, Kubota EH, da Silva CG, dos Santos Alves J, Hautrive TP, Rodrigues GS, et al. Banana inflorescences: A cheap raw material with great potential to be used as a natural antioxidant in meat products. Meat Sci. 2020;161:107991. 
10. Ganduri VSR. Evaluation of pullulan-based edible active coating methods on Rastali and Chakkarakeli bananas and their shelf-life extension parameters studies. J Food Process Preserv. 2020;44(4):e14378.

11. Jannah AM, Legowo AM, Pramono YB, Al-Baarri AN, Abduh SBM. Total bakteri asam laktat, $\mathrm{pH}$, keasaman, citarasa dan kesukaan yogurt drink dengan penambahan ekstrak buah belimbing. J Apl Teknol Pangan. 2014;3(2):7-11.

12. SR D, DD A, Nurhayati, MFS S. Teknologi Pangan. In: Direktorat Pembinaan Sekolah Menengah Kejuruan Departemen Pendidikan Nasional. 2008.

13. Hasan MU, Riaz R, Malik AU, Khan AS, Anwar R, Rehman RNU, et al. Potential of Aloe vera gel coating for storage life extension and quality conservation of fruits and vegetables: An overview. J Food Biochem. 2021;45(4):e13640.

14. Murmu SB, Mishra HN. Measurement and modelling the effect of temperature, relative humidity and storage duration on the transpiration rate of three banana cultivars. Sci Hortic (Amsterdam). 2016;209:124-31.

15. Sumiasih IH, Roedhy P, Darda E. Studi perubahan kualitas pascapanen buah manggis (Garcinia mangostana L.) pada beberapa stadia kematangan dan suhu simpan. In: Prosiding Seminar Nasional PERHORTI, Lembang. 2011. p. 23-4.

16. Sartika R, Poerwanto R. Pengaruh Suhu dan Kelembaban Udara Terhadap Shelf-life dan Karakteristik Buah Manggis (Garcinia mangostana L.) Selama Penyimpanan. Bogor Agric Univ. 2010;

17. Tursiska S. Pengaruh Suhu dan Lama Penyimpanan terhadap Mutu Buah Pisang Raja Bulu (Musa paradisiaca) setelah Pemeraman. Bogor: Departemen Teknik Pertanian IPB; 2007.

18. Wang $\mathrm{Y}$, Luo Z, Du R. Nitric oxide delays chlorophyll degradation and enhances antioxidant activity in banana fruits after cold storage. Acta Physiol Plant. 2015;37(4):74.

19. Salvador A, Sanz T, Fiszman SM. Changes in colour and texture and their relationship with eating quality during storage of two different dessert bananas. Postharvest Biol Technol. 2007;43(3):319-25.

20. Rahman MA, Hossain MA, Begum MM, Banu SP, Arfin MS. Evaluating the effects of 1methylcyclopropene concentration and immersion duration on ripening and quality of banana fruit. Postharvest Biol Technol. 2014;2:54-67.

21. Silaban SD, Prihastanti E, Saptiningsih E. Pengaruh Suhu dan Lama Penyimpanan Terhadap Kandungan Total Asam, Kadar Gula serta Kematangan Buah Terung Belanda (Cyphomandra betacea Sent.). Bul Anat dan Fisiol. 2013;21(1):55-63.

22. Kartika R. Pengaruh penambahan $\mathrm{Caco} 3$ dan waktu penyimpanan terhadap kadar vitamin c pada proses penghambatan pematangan buah tomat (Lycopersicum esculentum Mill). J Kim Mulawarman. 2016;8(1).

23. Ridhyanty SP, Elisa J, Linda ML. Pengaruh Pemberian Ethepon sebagai Zat Perangsang Pematangan terhadap Mutu Buah Pisang Barangan (Musa paradisiaca L). J Rekayasa Pangan dan Pertan. 2015;3(1):1-13.

24. Aminullah. Pasca Panen Jeruk. Jakarta Selatan: Transmedia; 2009. 